Hevko Ihor Vasilievich. Current problems of professional training of service specialists. Journal of Education, Health and Sport. 2020;10(1):158- 164. eISSN 2391-8306. DOI http://dx.doi.org/10.12775/JEHS.2020.10.01.018

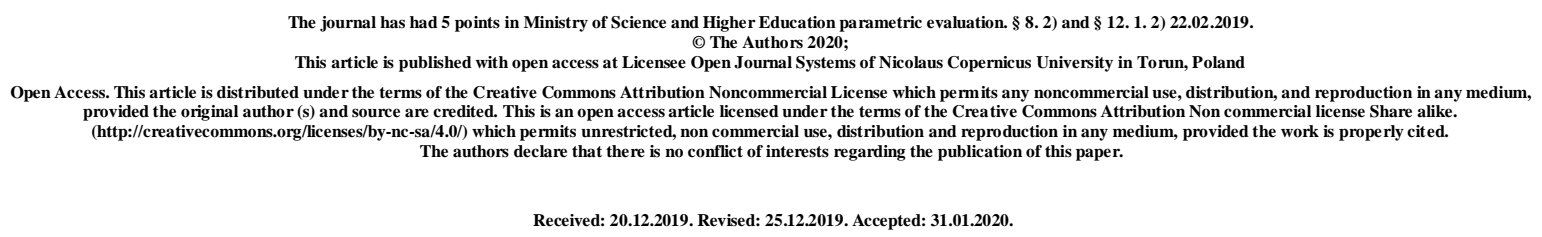

UDK 378.147

\title{
CURRENT PROBLEMS OF PROFESSIONAL TRAINING OF SERVICE SPECIALISTS
}

\author{
Ihor Vasilievich Hevko
}

\section{Ternopil National Pedagogical University Volodymyr Hnatyuk}

\begin{abstract}
The article is devoted to the current problem of professional training of future specialists in the field of services. The article describes the main features of the organization of professional training of specialists in the service sector, which form a complex of professionally important skills. The possibility of theoretical and pedagogical training of future specialists in the field of services is described. The article emphasizes that professional skills of service professionals have a complex structure and are formed in the process of learning and further professional activity. The high level of professional skills of service professionals will contribute to the development of a highly qualified specialist in the labor market, while respecting all the pedagogical conditions of professional skills formation.
\end{abstract}

Keywords: training; future specialists; services; skills; learning process. 


\title{
СУЧАСНІ ПРОБЛЕМИ ПРОФЕСІЙНОЇ ПІДГОТОВКИ ФАХІВЦІВ СФЕРИ ОБСЛУГОВУВАННЯ
}

\author{
I. В. Гевко \\ Тернопільський національний педагогічний університет \\ імені Володимира Гнатюка
}

\begin{abstract}
Анотація
Стаття присвячена актуальній на сьогоднішній день проблеми-професійної підготовки майбутніх фахівців сфери послуг. У статті описані основні особливості організації професійної підготовки фахівців сфери послуг, які формують комплекс професійно-значущих умінь. Описується можливість теоретико-педагогічної підготовки майбутніх фахівців сфери послуг. В статті акцентовано, професійні уміння фахівців сфери обслуговування мають складну структуру і формуються в процесі навчання і подальшої професійної діяльності. Високий рівень сформованості професійних умінь фахівців сфери обслуговування буде сприяти становленню висококваліфікованого фахівця на ринку праці, при дотриманні всіх педагогічних умов формування професійних умінь.
\end{abstract}

Ключові слова: підготовка; майбутній фахівців; сфера послуг; вміння; процес навчання.

Statement of the problem. Introduction. The development of the services market in Ukraine requires the availability of highly qualified service professionals, to whom new requirements are being raised in the current environment. To date, the service industry is expanding and occupies one of the first positions in shaping the country's economy. For many years, this industry has largely been a state structure, and today it is largely in the hands of private business.

Analysis of recent research and publications. The theoretical and methodological aspects of the state and prospects of development of the system of professional training of future specialists have been widely covered in the scientific works of many domestic and foreign scientists. The analysis and generalization of the accumulated experience forms an appropriate methodological basis for working out the main ways of modernization of vocational education. 
Basic material. Competence is interpreted as an integral characteristic of a student, that is, a dynamic set of knowledge, skills, abilities and personal qualities that the student is required to demonstrate after completing the educational program. In order to become a highly qualified specialist, a student must not only have the knowledge, skills acquired in the learning process, but also to apply them competently, using a creative approach in professional activity. Formed competencies hospitality industry specialist should be able to apply in various types of professional activity. The implementation of activities is impossible without the formation of a set of professional skills, which is an integral part of general cultural and professional competences [2, 3]. Professional skills of service professionals - a set of conscious, purposeful, learned mental and practical actions based on the productive use of knowledge about the professional activities of service professionals, functions and structure of communication, basic communication techniques that provide the implementation of the following activities: organization of service, Information Technology in education of marketing activity, control of quality of products and services, performance of works by working professions and positions of the employee in hospitality establishments.

The structure of professional skills of a specialist in the service sector has certain specific features and should include the following types of skills:

1) dialog-language - the ability to properly build written and oral speech, competently build a dialogue with staff, tactfully speak with the client;

2) information technology - the ability to bring to the staff information about the organization of work on customer service, the organization of technological process at the production, the need to monitor compliance with the technological process of production;

3) audio contact - the ability to listen to the client, assessing the quality of service and on this basis, developing proposals for its improvement;

4) analytical and managerial - the ability to analyze production situations, the ability to resolve industrial conflicts, to organize profitable business cooperation in the service process;

5) assessment and reflexive skills - the ability to draw conclusions on the basis of a study of the production process of the service company and to develop a program for the implementation of progressive management methods [1].

Consider the model of professional skills of service professionals, which defines the stages and pedagogical conditions of their formation. The idea of interconnecting theory and practice is at the heart of the formation of professional skills. The process of formation of professional skills should be based on the following approaches: systemic, problematic, personality-oriented, modularly competent and contextual. The systematic approach allows to 
create a holistic structure of the formation of professional skills and to determine the interconnections of the elements of the structure [4]. The problematic approach provides the formation of professional skills in the process of solving problematic situations of professional orientation. The personality-oriented approach takes into account the student's personality, its realization in professional activity, formation of professionally significant personal qualities.

The modular competence approach is the basis for the implementation of state educational standards, which provide for the formation of general and professional competencies by blocks - modules [7]. The contextual approach allows to train the specialist in the context of his future professional activity and to direct the educational process to the formation of professional skills of the specialist in the service sector. The formation of professional skills should be based on a system of principles: scientific, systematic, social partnership, integration, cross-curricular relations, professional orientation. The principle of social partnership is of great relevance in the conditions of today, in the training of service professionals. Social partnership is a system of relationships between educational institutions and economies that provide employment for graduates.

The principle is implemented through interaction with the professional community, namely:

- compliance with state standards developed to ensure the quality of work and services provided by professional service institutions;

- organizing targeted training of specialists in accordance with employers' requests;

- reviewing educational programs and work programs in the disciplines of training of employers in the region;

- providing students with educational and production activities of students;

- employment of graduates at enterprises of the region.

The development of professional skills in service professionals must be continuous and carried out in the process of theoretical, industrial and extra-curricular training. In the course of theoretical training, a set of knowledge about professional activity is formed in the course of studying the disciplines of professional and humanitarian cycles. Formation of professional skills is carried out in the course of performing tasks that include elements of professional communication: public speaking, creating professional problem situations, participation in discussions, conferences, etc. Formation of professional skills during industrial training is realized through the participation of students in professional trainings, 
workshops, preparation for obtaining a specialty. Trainings are a form of training that combines short theoretical seminars and practical skills development in a short period of time.

The teacher simulates situations that a future specialist may encounter and enables the student to find a solution for himself in a particular situation. The learning material is secured during the practice. Workshops are a method of generalizing and disseminating professional experience. Workshops are held in the production training. The master classes are available in two formats. The first is a master class held by a representative of a professional institution, the second is a teacher. In this case, students are leading, the teacher performs only an organizational function. Accordingly, students not only improve their professional skills, but also develop communication skills: conducting dialogue, proper construction of language structures, group management $[5,6]$.

Successfully completed industrial training provides the opportunity to obtain high qualifications in accordance with the requirements of the employer. Formation of professional skills in extracurricular training is carried out by independent participation of students in the preparation of master classes for groups of smaller courses, conducting professional competitions, research work, etc. The process of forming professional skills in future service professionals involves several steps.

The motivational-target stage provides for the development of motivation for the formation of professional skills in future professionals in the service sector through the introduction of students with the features of future professional activity, the development of needs to acquire a system of knowledge and skills; this is the stage of preliminary acquaintance with the system of formation of professional skills.

The cognitive-activity stage provides for the formation of a system of knowledge about the basics of service activities of the service sector enterprises during the study of special courses "Service activity", "Culture of hotel and restaurant business", "Psychodiagnostics", "Language etiquette", etc. Vocational activity - the stage of forming professional skills in terms of professional activity, which is created and required by the institutions of the service sector - social partners. Assessment-reflexive - the stage of evaluation and self-assessment of professional skills of service professionals, which includes performing tasks and exercises in theoretical, practical classes, during extracurricular work, and also shows the possibilities of realization in professional activity. The following pedagogical conditions are defined for realization of the model of formation of professional skills of specialists of the service sphere:

- Increasing motivation for the educational process; 
- social partnership with representatives of professional institutions;

- realization of stages of formation of professional skills;

- unity of educational activity of students;

- the availability of educational and methodological support for the formation of professional skills;

- development of a criterion-diagnostic apparatus for assessing the formation of professional skills.

In order to assess the development of professional skills in future service professionals, there are three levels of professional skills:

1. High level: constant motivation for the process of formation of professional skills; possession of all kinds of professional skills in solving problematic tasks; in practice, professional skills are realized consciously, independently and without mistakes; objective self-assessment of the level of professional development.

2. Intermediate level: poorly expressed motivation for the process of formation of professional skills; superficial understanding of the essence of technological processes of a certain profile; non-systematic possession of professional skills; objective self-assessment of the level of formation of certain types of professional skills.

3. Basic level: lack of motivation for the process of formation of professional skills; possession of some or all kinds of professional skills; in practice, professional skills are not realized consciously, with mistakes; inability to objectively assess the level of professional skills.

Conclusion. Professional skills of service professionals have a complex structure and are formed in the process of training and further professional activity. The high level of professional skills of service professionals will contribute to the development of a highly qualified specialist in the labor market, while respecting all the pedagogical conditions of professional skills formation.

\section{References:}

1. Vasina, EV Methodical manual. Basic skills and their place in the content of professional educational programs. [SPb. Scythia Publishing House, 2001 - 32 p.

2. John, R. Walker. Introduction to Hospitality M: UNITI, 1999. - 262p.

3. Kvartalnov, VA Theoretical bases of formation and development of the system of continuous professional education in the sphere of tourist activity: author. diss. doc. ped. Sciences: 13.00.08 / Kvartalnov, Valery Alexandrovich; M .: 2000. - 35 p. 
4. Chitaeva, OB New professions in the commercial sphere: methodology, content, standards. Moscow: APO Publishing Center, 2002. - 310 p. 5. Pavitskaya ZI Formation of students' communicative skills in the classroom: dis. ... Cand. ped. Sciences: 13.00.08 / Pavitskaya, Zoya Ivanovna; Kazan, 1999. - 175 p. 